Even with the present widespread use of insecticides, most human beings are exposed to not more than traces of these agents, while large doses were used in this work on rats, and even more so in the investigation on Drosophila quoted ${ }^{6}$. Nevertheless, it would appear that broad investigations of growing cells and insecticides are to be encouraged.

This work was supported in part by a grant 605-7146 from the Ontario Department of Health.

\section{W. KaLOW}

A. Marton

Department of Pharmacology, University of Toronto.

${ }^{2}$ Holmstedt, B., Pharmacological Rev., 11, 567 (1959).

${ }^{2}$ O'Brien, R. D., Toxic Phosphorus Esters, 320 (Academic Press, New York, 1960)

" Wurkhalter, A., Featherstone, R. M., Schueler, F. W., and Jones, M., J. Pharm. Exp. Therap., 120, 285 (1957).

"Hazleton, L. W., and Holland E. G., A.M.A. Arch. Indust. Hyg., 8, 399 (1953).

${ }^{5}$ Barnes, J. M., and Denz, F. A., J. Hyg., 49, 430 (1951).

- Rapoport, I. A., and Kostyanovskii, R. G., Doklady Akad. Nauk S.S.S.R. (translated issue, Amer. Inst. Biol. Sci., 131, 246 (1960)). ${ }^{7}$ Ross, E., and Sherman, M., Poult. Sci., 39, 1203 (1960).

"Singer, M., Davis, M. H., and Arkowitz, S., J. Embryol. and Exp.

Jowe, C. R., Brit. Med. J., ii, 673 (1959).

\section{5-Hydroxy-3-indoleacetamidine: a New Type of Blocking Agent against 5-Hydroxytryptamine}

THE possible role of 5-hydroxytryptamine (5-HT) regarding its action on the mammalian nervous system has been discussed repeatedly. However, pharmacological investigations were not very successful in clarifying this role. The well-known approach of using 'specific' antagonists against the neural effects of 5-HT has been stranded on two grounds: (a) the commonly known blocking agents of 5-HT are in fact only antagonists of 5-HT on smooth muscles, and $(b)$ the actions of 5-HT on nervous receptors, except for a few peripheral sensory and ganglionic receptors, are not adequately explored. Recent investigations ${ }^{1}$ demonstrate that even those agents which were shown before to block certain hypothetical nervous receptors of the guinea pig ileum ${ }^{2}$ are of fairly low potency and/or selectivity to the ganglionic stimulant action of 5-HT. The tachyphylaxis observed in the ganglionic action of 5-HT suggested the use of compounds structurally closely related to 5-HT as its possible antagonists. One of these compounds, 5-hydroxy-3-indoleacetamidine (5-HTA), which was first described as a 5-HT-like stimulant agent ${ }^{3}$, showed the following unique characteristics :

(1) In accordance with the data of Woolley and Shaw $^{3}$ 5-HTA was found to have pressor action on the nembutalized dog. It also stimulated the respiration markedly after intravenous injection of 10-20 $\mu \mathrm{gm} . / \mathrm{kgm}$. Eighty $\mu \mathrm{gm} . / \mathrm{kgm}$. intravenously blocked the pressor, reflex-bradycardic and respiratory stimulant actions of 5-HT for a few minutes. 5-HT itself, up to $160 \mu \mathrm{gm}$./kgm., was unable to influence significantly the actions elicited by $20-40 \mu \mathrm{gm} . / \mathrm{kgm}$. 5.HTA.

(2) A stimulant action of 5-HTA was found on the pelvic nerve-bladder preparation of the dog, but this action only partly resembled that of 5-HT. Given in doses of $1-4 \mu \mathrm{gm} . / \mathrm{kgm}$. intra-arterially 5-HTA evoked a twitch-like rapid contraction. 5-HT in the same dose-range produced a twitch-like reaction at first, followed by a slow contractile second phase $^{4}$. The action of 5-HTA and the first phase of the 5 -HT action were not inhibited by $0.2 \mathrm{mgm} . / \mathrm{kgm}$. bromo-lysergic acid diethylamine. Morphine, which is known to block nervous receptors sensitive to 5 -HT (refs. 2, 4, 5), was found to be effective against 5-HT and 5-HTA in doses of 1-2 mgm. $/ \mathrm{kgm}$. No blockage against 5-HT has been observed on the bladder with the small doses of 5-HTA (1-4 $\mu \mathrm{gm}$./ kgm.) used.

(3) On the isolated rat uterus 5-HTA up to 0.5 $\mu \mathrm{gm} . / \mathrm{ml}$. did not show stimulatory action, whereas $0.01 \mu \mathrm{gm} . / \mathrm{ml}$. 5-HT stimulated the uterus. 5-HTA in the concentration mentioned diminished the action of 5-HT only slightly (dose-ratio: 4 ).

(4) Intra-arterial injections of $5-20 \mu \mathrm{gm}$. 5-HT and 5-HTA produced contractions of the cat nictitating membrane ('Nembutal' anæsthesia). With temporary occlusion of the external carotid artery, the threshold dose of 5-HT was lowered 2-3 times. With this condition the stimulation of the membrane is mainly produced indirectly by stimulating the superior cervical ganglion ${ }^{5}$. In contrast, the threshold dose for 5-HTA was rather increased by occlusion, indicating that its stimulant action was chiefly a direct effect on the nictitating membrane. 4-20 $\mu \mathrm{gm}$. 5-HTA considerably diminished the ganglionic stimulation produced by 5-10 $\mathrm{\mu gm}$. 5-HT (occluded external carotid artery). The same doses of 5-HTA were less or not effective against the direct stimulatory action of 5-HT on the nictitating membrane (open external carotid artery).

(5) On the inferior mesenteric ganglion preparation of the eat 6 no change or slight increase of the spontaneous post-ganglionic action potentials has been observed by intra-arterial injections of $1-20 \mu \mathrm{gm}$. 5 -HTA. The ganglionic stimulant action of $2 \cdot 5$ $10 \mu \mathrm{gm}$. 5-HT, however, was reduced by $1 \mu \mathrm{gm}$. and inhibited by 5-20 $\mu \mathrm{gm}$. 5-HTA given 30 sec. and $4 \mathrm{~min}$. before 5-HT. The stimulating action of 1,1-dimethyl, 4-phenyl-piperazinium iodide was unaltered by the same doses of 5-HTA.

5-HTA is the first compound which shows considerable antagonism against the ganglionic actions of 5-HT. Whereas it has stimulant properties on certain organs (urinary bladder, nictitating membrane) it usually lacks stimulant effects on the superior cervical and inferior mesenteric ganglia in the doserange used. So far as its relative potency is concerned. 5-HTA is at least twenty times as potent as either LSD or bromo-LSD, cocaine and morphine against the ganglionic stimulant action of 5 -HT. It is also more potent than bromo-LSD in preventing the reflex respiratory stimulant action of 5-HT. The blocking action of 5-HTA to 5-HT on the rat uterus is weak, inferior to that of LSD, bromo-LSD, chlorpromazine and of many other 'smooth muscle' type 5-HT antagonists. The compound seems to have a high degree of selectivity to certain nervous receptors sensitive to 5 -H'T.

Geigy Research Laboratories, Ardsley, New York.

'Bindler, E., and Gyermek, L., Fed. Proc., 20, 319 (1961).

${ }^{2}$ Gaddum, J. H., and Picarelli, Z. P., Brit. J. Pharmacol., 12, 323 (1955).

'Woolley, D. W., and Shaw, E., J. Pharm. and Exp. Therap., 121,13 (1957).

' Gyermek, L., The Pharmacologist, 2, 89 (1960).

- Trendelenburg, U., Brit. J. Pharmacol., 12, 79 (1957).

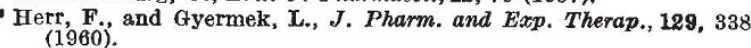

